\title{
THE PREACHER AND THE STUDY OF SOCIOLOGY.
}

BY SHAILER MATHEWS, DEAN OF THE DIVINITY SCHOOL OF THE UNIVERSTTY OF CHICAGO.

I am not a sociologist. I am a theologian, or at least I am trying to be one. Yet I believe that there is much for the minister to gain from the study of society. Not that sociology can replace the Gospel. Whoever thinks that should never be a minister in an evangelical church. The real place of the study of society in a minister's curriculum, both in and after his theological seminary course, is that of assisting him to gain a new sense of his office and a new valuation of his message.

$I$ use the word society in a broad way to indicate a community composed of persons acting together and subject to approximately the same conditions. Its nature has been roughly set forth in terms of an organism, but of late this analogy has been to a considerable extent abandoned and psychology rather than biology has been brought into the service of social thinkers. Yet, however a minister approaches the study of society as distinct from that of isolated individuals, he will find himself coming to appreciate anew the great evangelic truths with which, in Christ's stead, he goes forth, beseeching the world to be reconciled to ts God.

I.

In the first place, such study will enable a man to appreciate better the reality and the awfulness of sin.

You cannot save people who do not want to be saved. Jesus himself declared that he was sent to heal not the well, but the sick. One of the greatest dangers that besets our modern world is moral complacency. Sometimes the preacher, especially if he be in any sense in revolt against the older type of preaching, falls under the spell of the temptation to flatter people into the 
Kingdom of God. Sometimes he tries to utter literary essays, introducing religious matters, as it were, surreptitiously into his discourse. But the world cannot be saved by stereopticon lanterns. It cannot be entertained into righteousness. Until both the preacher and the people to whom he preaches come to realize that $\sin$ is something more than a mistake, that it is a contaminating influence in the social atmosphere, a backward pull within the individual himself, it is not likely that the Gospel will be warmly welcomed. For the Gospel is a message of healing and salvation only to those men who feel the need of such healing and salvation. Jesus has no message for bad men, except the call of Jonah to the men of Ninevehthe call to repentance.

Now, an honest preacher of the Gospel knows only too well the meaning of sin in his own life. He shares with Paul and Augustine, in fact with every religious teacher the world ever knew except Jesus Christ, a sense of the sinfulness of his own soul. And it is his business to arouse this sense of personal unworthiness on the part of all his hearers. This duty is met most effectively when he comes to the study of sin, not only from the point of his own individual experience, but from the study of society as a whole. He sees that sin tends to socialize itself and to perpetuate itself in institutions, and within the entire environment into which men are born and the more intimate environment into which they enter when they undertake to make their living. He sees, too, that sin is not generally committed because it is sinful, but because it is believed to lead to pleasure or to wealth.

Now, pleasure and wealth are by no means identical, but the student of society sees only too clearly that the two often become united, and thus come to present a front that tends steadily to make the work of the Gospel more difficult. The problem of the theater and other forms of amusement is no longer one that can be settled from the individual point of view. They have become great social institutions involving enormous capital and even far more enormous expenditure. As such they are so deeply wrought into our social fabric as to be utterly impervious to the denunciation of individual devotees to pleasure. 
When the search for pleasure is commercialized it is one of the most potent of the forces making toward social debilitation, if not actual sin-a sin that is something more than a matter of theological hand-books. A minister who has once studied carefully a section of the city from which householders have been driven to be replaced by saloons, brothels and immoral theaters, does not have to remember definitions of sin he learned in his class in theology. He knows it to be a force that is working its damnable result, ultimately always in individuals, but immediately in communitios. He sees that if these individuals are to be saved, something has to be done to check the influences of commercialized vice upon children, as well as upon adults. And thus he comes to face the entire range of problems associated with the family, penology and municipal regulation of social evils.

Further, in the same proportion as his study of society is more than theoretical, does the preacher come to see that the problem of sin has become further complicated by the present tendency in the individual world toward corporation and labor organizations. In fact, there may be said to be growing up a new sort of sin, that of the corporation. As individuals, men and women may be charming fathers and mothers, kindly and even devoted to our churches, but as owners of stock in corporations or as members of labor unions they may connive at, if not indeed participate in, actions which, if not illegal, certainly are contrary to the spirit of justice and love. This is not to say that corporations and labor unions are wrong. It is only to say that they complicate the problem of wrong. The minister who comes face to face with the question of the enforcement of factory laws for the protection of workmen, women and children, comes to see that in our modern life this new sort of sin is one of the most difficult to deal with; even to get defined as sin. But few men, after having faced these facts, can ever be content to treat sin as simply a question of merely individual relations. The very moral indifference of certain corporations and their constant tendency to regard themselves as impersonal combinations, the willingness of labor organizations to justify violence in the name of a noble cause, all alike will compel 
him to new activity in stimulating the moral conscience. He will not necessarily attack the corporations or labor unions as such, he may never use the words, but he will so devote himself to the work of moral agitation and education as to make men feel that the laws of right and wrong and love extend wherever men go.

\section{II.}

But the preacher will get from his social studies a sense of the impotence of the unorganized individual to combat the social evils which now face the world, and thus we come in sight of the second service that the study of sociology may render the minister. It will give him a new and more effective conception of the church.

I use the word church as a general term without meaning to commit myself to any ecclesiastical theory. In strictness it can be applied only to a body of Christian believers who have united themselves according to the principles of the New Testament. But we all use the word in a larger sense to include the idea not only of these local organizations taken severally, but also in a loose way as a generic term, as a sort of convenient tool for expressing the idea of organized rather than unorganized religious people.

No man who studies society can for a moment deny that religion has a place in social development and that such a place is also to be assigned churches as social institutions. No man has ever been of great significance in history who has not in some way institutionalized his ideals. The church is the institutionalized Gospel. There are doubtless Christian people who, for exceptional reasons, may never join any local body of believers, but speaking generally, they amount to very little as religious forces. Even if they could all be brought together, they would be only a mob. And a mob, however much it may talk and shout and destroy, is not to do constructive work. The Greeks beat the enormously greater armies of the Persians because they were disciplined. The church is the army of the Lord. In the same proportion as it is fulfilling its mission is it 
training men and women in efficiency. It is not simply a group of people who have been drawn together by the common hope of salvation. It is rather a group of Christians who are being trained to bring the Gospel to their world.

No one can understand this quite as clearly before as after he has studied the structure of society. He sees various institutions standing for different functions of social life; the state for government, the school for secular education, the courts for justice. But he finds no institution except the church devoting itself to the production of good men and women. There are reform organizations, of course, that endeavor to dispel the works of evil, but the church is unique among the great social agencies in that it actually succeeds in creating, with Gud's help, regenerate life. Now the student of society, if he be really scientific rather than Utopian, sees that society without regenerate individuals is as impossible as a marble house without marble blocks. He inevitably comes to realize the real need not only of bringing souls into right relations with God, but in grouping them together for more efficient service with God.

The study of society will show the minister, furthermore, that he must unify and concentrate his conception of the real function of the church in society. He will see it is not to undertake every sort of social reform; that one of the chief dangers that beset it is the dissipation of its strictly spiritual energies. I know there are those who believe that the chief object of the work of the church should be miscellaneous reform. Every institution has its critics, and in this particular the church is like the theological seminary. If theological seminaries were to teach all the courses which their critics suggest, the theological student would not get out into his parish younger than Moses escaped from Egypt. And even thus he would be so weakened by the cuisine of his educational house of Pharoah, its table-d'hote of political economy, political science, hypnotism, basketball, religious pedagogy, philosophy, biology, higher criticism, practical athletics, advertising, management of moving pictures and practice of psychotherapeutics as to need another forty years' retirement to recover his balance of mind 
and a practical-minded father-in-law to assist him in organizing the people he was trying to lead out of bondage.

Similarly in the case of the church: Its supreme spiritual function is in danger of being obscured by those who would have us see in it, not the body of our Christ, but a reform organization. Far be it from any one of us to minimize the importance of well-directed efforts to make a church a social influence in the way of so-called institutional work. But the minister who thinks his church is successful because it teaches girls to sew and boys to play basketball, and men to listen to political speeches and women to substitute missionary societies for bridge whist, has a very imperfect conception of what the church should do as a social institution. All of these accomplishments are to be commended, but they are no more the supreme social duty of the church than feeding the multitude was the supreme mission of Jesus. In so far as they are the social expression of the religious impulses of Christians, they are highly commendable; in so far as they are the substitutes for the spiritual ministrations of a church, they are dangerous. And no man knows this better than he who, after a careful study of the structure of society, comes to feel that men need God and his salvation if social evolution is to move on toward the Kingdom of Heaven. Unless I mistake, there is a decided need of emphasizing this truth which the study of society brings home in a day when the church is being particularly subjected to criticism. None would say that the church is perfect, but no man who knows churches in any broad way, who studies them from within rather than from without, will fail to admit that, speaking generally, the conscience of the community lies in the church members and that the morality of church members is superior to the average of morality. There are always moral parasites in a community who apparently are as good as those upon whose religious spirit they feed. But if one could imagine what the state of a city would be in which there were no Christian churches, he would then be able to judge the social significance of the church even as it is today. We may well urge our church organizations to wider sympathies, to more sacrifice and to more strenuous endeavor for the 
brotherhood of man, but let us not forget that the very reason that we are impatient of their imperfections is our profound conviction that they are the one body from whom such ideals can be expected. For they are, with God's help, producing the raw material, so to speak, out of which all sorts of municipal and social reforms can be created. And this comes to no man so effectively as to him who, after the broad study of society, comes to appreciate what the church, with all its failings, has been to history as its central spiritual force, and what a center of moral ambition and energy it is and even more is becoming today.

\section{III.}

In the third place, sociological study will make the minister feel more completely the sovereignty of God and the need of divine help in all his efforts at reform and evangelization.

I must confess that many a time the study of actual social conditions in our great cities fills me momentarily with a sense of despair. So mighty do the forces of evil appear, so universal is the tendency to answer all questions in terms of force rather than in terms of love; so apparently ineffective are the agencies of good as to make one hesitate and at times even to despair. Now, it is at such moments that the minister brings to his social observation the optimism of the Gospel. He sees new meaning in that term which so frequently he has used conventionally - "The Kingdom of God". . And more than all does he come to feel the force of the cry of Jesus, "The Kingdom of God is at hand. Repent and believe the good news".

For we cannot trust so-called natural evolution to bring about the salvation we desire. If God be not working in the world, we Christians are indeed in a sorry plight. We have staked our very souls on the belief that we are not laboring in vain, that through the ages one increasing purpose runs and that God is working out that gracious plan we think we see disclosed in history and in particular in our Bible.

But how much more God means to us when we believe that he not only made the world and the universe and mankind, 
but that in some way we can as yet only faintly trace, his purpose of love is being wrought out in the world despite sin. The church is his body. And from such a point of view we get a Gospel of new meaning in that bold word of Paul, the church "is the fullness of him that filleth all things". The student of history comes to see this. Benjamin Kidd himself has helped us see it a little more plainly than we saw it before, but most of all does the Gospel itself supplement our social study and give it new meaning. By that study we not only come to feel our greater need of God, but we see also that God is actually working in society as well as in individuals. We cannot minimize the individual. In my opinion salvation stands as a supreme end of all the great history of the race that lies behind us. But nonetheless can we appreciate that whatever God can do with the individual, we must trust him also as he works in that society in which the individual is environed and of which he forms a part.

And to my mind this is the end of the matter so far as the minister's study of sociology is concerned. If such a study does not enable him better to bring God to the human soul, give him a keener appreciation of humanity's needs of the divine salvation, a firmer grip upon the Gospel message of Jesus Christ and a keener perception of the opportunity and the study of the church, it has proved a failure. But I cannot befleve that such a failure can ever wait upon an honest search for a meaning in our social life. I have seen too many men brought by such study to deeper seriousness of purpose and more intense spirit of self-sacrifice for Jesus Christ to doubt its efficacy. After every effort I make to apprehend the meaning of social life, its needs and its possible salvation, I find myself saying over again with Paul, "I am not ashamed of the Gospel of Jesus Christ: for it is a power of God unto salvation"- to the individual first and also to society. 